10IKC-140

\title{
BANDED ALKREMITE XENOLITHS FROM NYURBINSKAYA KIMBERLITE PIPES (NAKYN FIELD, YAKUTIA)
}

\author{
Sablukov SM ${ }^{1}$, Sablukova LI $^{1}$, Stegnitsky YuB ${ }^{2}$ and Karpenko MA ${ }^{3}$ \\ 1 Rusgeo Ltd, Moscow, Russia, \\ 2 NIGP ALROSA Co. Ltd., Mirny, Russia, \\ 3 Nyurbinskaya Mine ALROSA Co. Ltd., Mirny, Russia
}

\section{INTRODUCTION}

Alkremite xenoliths with mineral paragenesis "pyrope garnet + spinel" (Ponomarenko, 1975, 1980) rarely occurring in kimberlites were found in Yakutia (Udachnaya pipe), Africa (Roberts-Victor and Kaalvallei pipes, Bellsbank dike), and the United States of America (Moses Rock). Alkremite xenolith was identified for the first time by us in kimberlites of the Nyurbinskaya pipe within the Nakyn field, Yakutia. Alkremites are probably products of magmatic differentiation and crystallization of mantle melts, that's why studies of these rare rocks is of great interest.

\section{KIMBERLITES AND MANTLE XENOLITHS OF THE NAKYN FIELD}

Nakyn field kimberlites (Fig. 1) differ drastically from kimberlites of other Yakutian kimberlite fields (Cherny et al., 1998), primarily, by being free of picroilmenite megacrysts and extremely geochemically depleted, with peculiarly low concentration of $\mathrm{Ti}, \mathrm{Fe}$ and all incompatible elements except for $\mathrm{K}, \mathrm{Rb}$ and $\mathrm{P}$. By mineralogical, petrographic and geochemical characteristics, kimberlites of Nakyn field are close to kimberlites of Group 2, and by $\mathrm{Nd}-\mathrm{Sr}$-isotopic characteristics they are similar to kimberlites of Group 1.

Mantle xenoliths abound in rocks related to all intrusion phases in the Nyurbinskaya pipe, varying in size from 2-6 $\mathrm{cm}$ to $21 \mathrm{~cm}$. In all, more than 500 nodules were examined. The xenoliths are dominated by garnet peridotite and clinopyroxenite and chrome spinel peridotite (Sablukova et al., 2008), with a minor proportions of spinel peridotite and eclogite Groups A and B, (after Coleman et al., 1965). In addition, rare megacrysts of orange Ti-association garnet and macrocrystals of orange and red garnet (eclogite suite) also occur. Mantle xenoliths have a granulose structure. Cataclastic peridotite is almost completely lacing, while banded (layered) rocks and rocks with unbalanced mineral suites are quite abundant. Approximately $10 \%$ of garnet peridotite and clinopyroxenite xenoliths contain picroilmenite accessories.

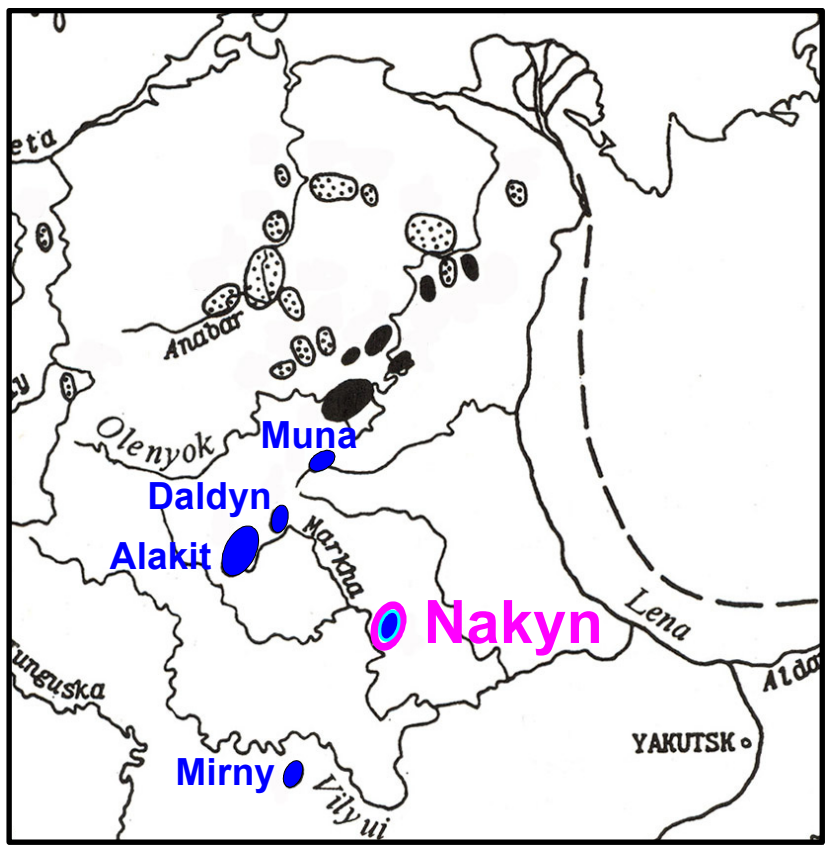

Fig. 1. Distribution of kimberlite fields on the Yakutia Province.

The abundance and characteristic size of mantle xenoliths and the sharp predominance of garnet peridotite makes the Nyurbinskaya pipe kimberlites similar to kimberlite rocks from other Yakutian kimberlite fields. Along with this, kimberlites of the Nyurbinskaya pipe differ drastically from other Yakutian kimberlites by their high chrome spinel peridotite content, and by the presence of picroilmenite accessories and clinopyroxene with peculiar mineral chemistry in mantle xenoliths, and absence of characteristic picroilmenite megacrysts. 


\section{$10^{\text {th }}$ International Kimberlite Conference, Bangalore - 2012}

Besides typical for kimberlite xenoliths mantle xenoliths of an unusual composition, including alkremite xenoliths can be observed in Nyurbinskaya pipe.

\section{ALKREMITE XENOLITHS}

Alkremite xenolith (sample H-678) is oval in shape and $6.2 * 4.8 * 4.2 \mathrm{~cm}$ in size with (and 188 grams of weight) a pronounced subparallel banded structure (Fig. 2,3).

The structure is formed by layers of the spinel grains in a predominant garnet matrix.
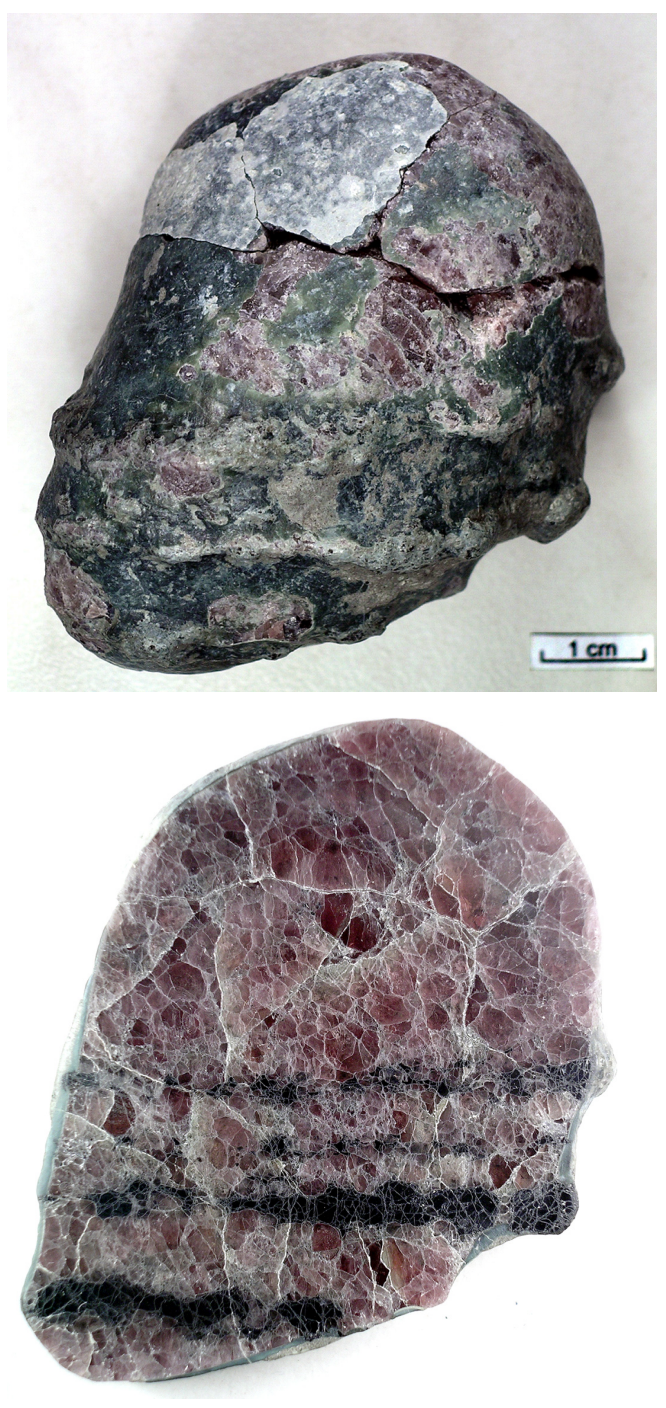

Fig. 2. Alkremite xenoliths in the Nyurbinskaya pipe: top - general appearance; bottom - slice section.

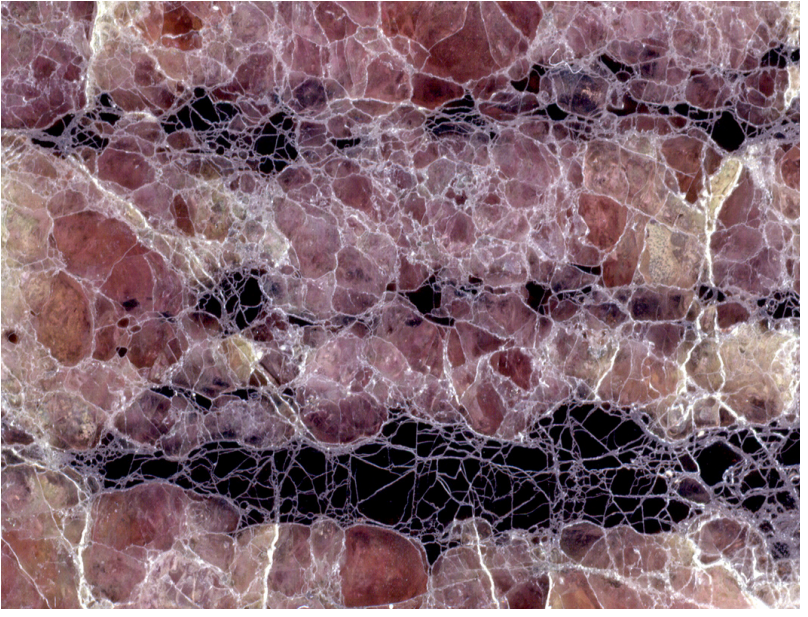

Fig. 3. Banded structure of the alkremite, slice section. Field $2.5 \mathrm{~cm}$.

Pale pink garnet $(85 \%)$ occurs as low-Cr pyrope (almandine(13)-grossular(15)-pyrope(67)) and is characterized by the high $\mathrm{MgO}$ content $(18.77 \%)$, elevated contents of FeOtot $(7.83 \%)$ and $\mathrm{CaO}(7.51 \%)$, and very low contents of $\mathrm{Cr}_{2} \mathrm{O}_{3}(0.16 \%)$ and $\mathrm{TiO}_{2}(0.07 \%)$ (Table-1). Garnets of similar composition (but with higher contents of $\mathrm{MgO}$ and lower contents of $\mathrm{CaO}$ ) in a plenty meet in porphyritic kimberlites pre-pipe dike of the Nyurbinskaya pipe (sample HD-137, Table-1).

Greenish brown spinellid (15\%) is characterized by the high contents of $\mathrm{Al}_{2} \mathrm{O}_{3}(65.85 \%)$ and $\mathrm{MgO}(22.61 \%)$, low contents of $\mathrm{Cr}_{2} \mathrm{O}_{3}(2.39 \%)$ and FeOtot (6.84\%), and by composition corresponding to hercynite spinel.

Table-1. Chemical (wt. \%) and oxygen isotope composition of alkremite minerals.

\begin{tabular}{|c|c|c|c|c|c|}
\hline Sample & \multicolumn{2}{|c|}{ H-678 } & \multicolumn{3}{|c|}{ HD137 } \\
\hline Minerale & Grt & $\mathrm{Sp}$ & Grt & Grt & Grt \\
\hline $\mathrm{SiO}_{2}$ & 41.63 & - & 41.99 & 42.01 & 41.82 \\
\hline $\mathrm{TiO}_{2}$ & 0.07 & 0.02 & 0.07 & 0.12 & 0.31 \\
\hline $\mathrm{Al}_{2} \mathrm{O}_{3}$ & 23.72 & 65.85 & 23.78 & 23.82 & 22.75 \\
\hline $\mathrm{Cr}_{2} \mathrm{O}_{3}$ & 0.16 & 2.39 & 0.11 & 0.12 & 0.61 \\
\hline $\mathrm{FeO}$ & 7.83 & 6.84 & 7.48 & 7.38 & 7.15 \\
\hline $\mathrm{MnO}$ & 0.22 & 0.01 & 0.29 & 0.35 & 0.41 \\
\hline $\mathrm{MgO}$ & 18.77 & 22.61 & 20.76 & 20.79 & 21.92 \\
\hline $\mathrm{CaO}$ & 7.51 & - & 4.80 & 4.92 & 3.83 \\
\hline $\mathrm{Na}_{2} \mathrm{O}$ & 0.00 & - & 0.02 & 0.03 & 0.08 \\
\hline Total & 99.91 & 97.72 & 99.30 & 99.54 & 98.88 \\
\hline Pyrope, \% & 67.1 & - & 73.69 & 73.76 & 78.22 \\
\hline$\delta^{18} \mathrm{O}, \%$ & 5.56 & - & - & - & - \\
\hline
\end{tabular}




\section{$10^{\text {th }}$ International Kimberlite Conference, Bangalore - 2012}

Trace-element analyses of garnet were made with LAICP-MS at the Centre for Isotope Research, VSEGEI, St.Petersburg, Russia. Methods and operating conditions have been described by Norman et al., 1996.

Alkremite garnet is characterized by a flattened type of REE distribution with depletion in the area of HREE and enrichment in the area of LREE (Fig. 4).
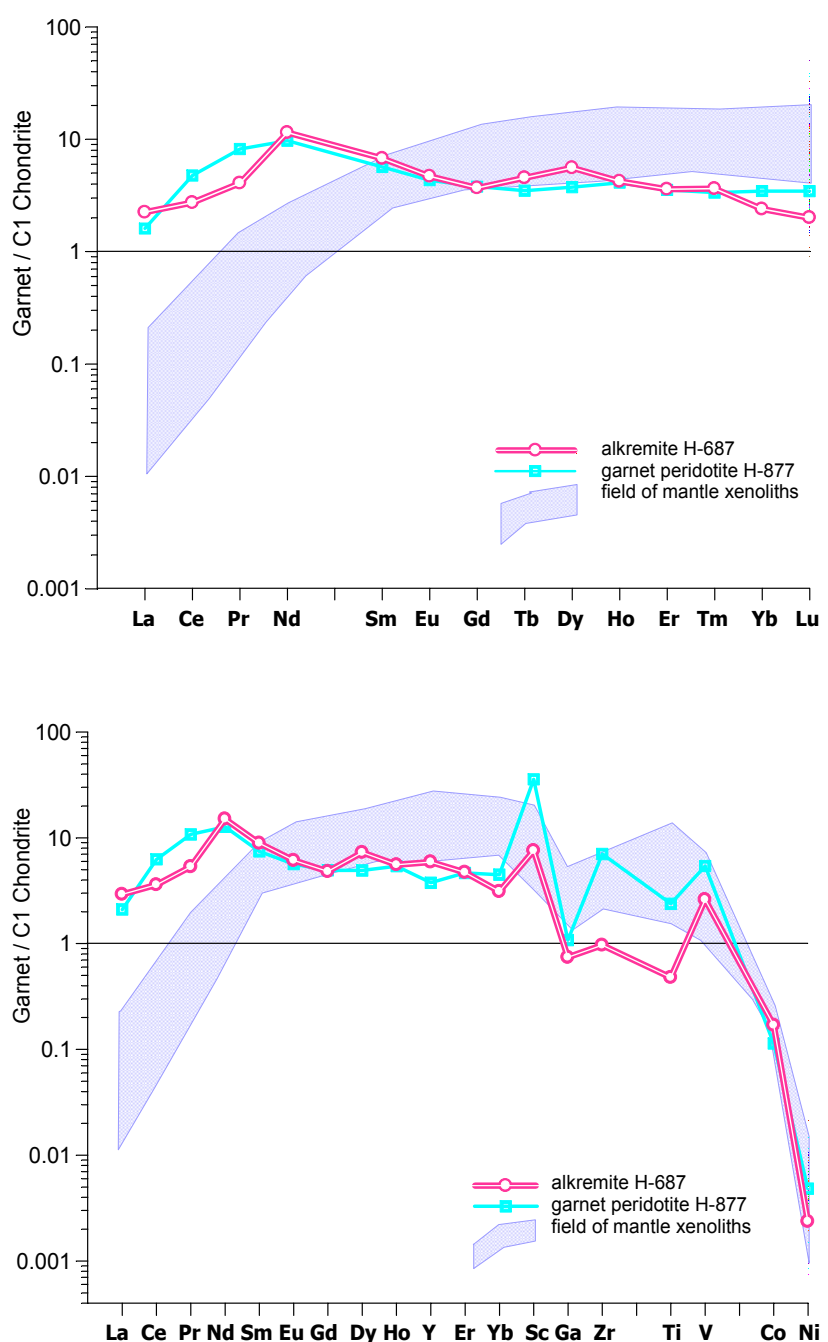

Fig. 4. REE (top) and trace element (bottom) patterns of alkremite garnets in the Nyurbinskaya pipe (normalized after McDonough and Sun, 1995)

Out of the garnets of various types of mantle xenoliths (peridotites, pyroxenites, eclogites and megacrysts) of Nyurbinskaya pipe (our unpublished data, 34 samples), a similar range of distribution of rare earth metals can belong only to high-chromium garnet $\left(13.03 \%\right.$ of $\left.\mathrm{Cr}_{2} \mathrm{O}_{3}\right)$ of lherzolite paragenesis from garnet peridotite xenolith (sample No H-877). The difference of alkremite garnet from garnets of most mantle xenoliths of Nyurbinskaya pipe is in increased content of light rare earth metals and a low content of incompatible elements: $\mathrm{Zr}, \mathrm{Ti}$, and $\mathrm{Ga}$ (at chondrite level or even lower, which is typical of the depleted mantle).

Isotopic compositions of oxygen in garnet from alkremite xenoliths of the Nyurbinskaya pipe were determined. Isotopic composition of alkremite garnet $\left(\delta^{18} \mathrm{O}\right.$ $=5.56 \%$ oo $)$ corresponds to the typical mantle values $\left(\delta^{18} \mathrm{O}=\right.$ $5.5+/-0.4 \%$, after Mattey et al., 1994) (Fig. 5).

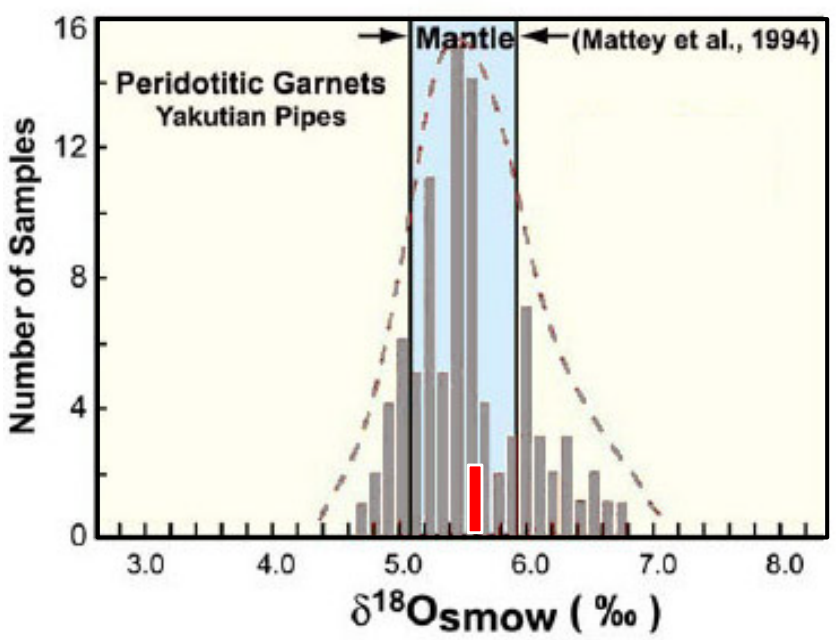

Fig. 5. Oxygen isotope values for alkremite garnet from the Nyurbinskaya pipe (diagram after Taylor et al., 2003).

We have completed the definition of Nd-Sr-isotopic characteristics of the alkremite sample (Table-2). The most interesting indicator here is a very ancient model age of alkremite of relativele depleted mantle - 5 billion years, although judging by the high ratio ${ }^{147} \mathrm{Sm} /{ }^{144} \mathrm{Nd}$ the isotopic system could be compromised.

Table-2. Sr-Nd-isotopic composition of alkremite xenoliths

\begin{tabular}{|c|c|}
\hline Sample & H-678 \\
\hline $\mathrm{Rb}, \mathrm{ppm}$ & 8.866 \\
\hline $\mathrm{Sr}, \mathrm{ppm}$ & 17.64 \\
\hline${ }^{87} \mathrm{Rb} /{ }^{86} \mathrm{Sr}$ & 1.457 \\
\hline${ }^{87} \mathrm{Sr} /{ }^{86} \mathrm{Sr}$ & $0.734933+/-9$ \\
\hline $\mathrm{Sm}, \mathrm{ppm}$ & 1.587 \\
\hline $\mathrm{Nd}, \mathrm{ppm}$ & 5.529 \\
\hline${ }^{147} \mathrm{Sm} /{ }^{144} \mathrm{Nd}$ & 0.1735 \\
\hline${ }^{143} \mathrm{Nd} /{ }^{144} \mathrm{Nd}$ & $0.511796+/-5$ \\
\hline $\mathrm{T}_{(\mathrm{Nd})} \mathrm{DM}, \mathrm{BA}$ & 5.08 \\
\hline
\end{tabular}




\section{$10^{\text {th }}$ International Kimberlite Conference, Bangalore - 2012}

TR-parameters of formation of alkremite were performed for the composition of garnet, with using the "PTQuic" Program: the temperature was determined by thermometer Canil, 1999, and the pressure of the barometer Grutter, Latti \& Menzies, 2006.

High temperature $\left(931^{\circ} \mathrm{C}\right)$ and rather low pressure (13,6 kbar), confirm magmatic character of alkremite formation.

\section{CONCLUSIONS}

Judging from ${ }^{18} \mathrm{O}$ isotopy, compositions of garnet and spinel, and banded (laminated) structure, the alkremite sample is a fragment of the coarse-crystalline mantle plutonic rock with the elements of igneous layering, which is unlikely related to other high-alumina rocks ("corganites", “cograspinites", and "grospydites").

\section{References}

Canil D. (1999) The Ni in garnet geothermometer: calibration at natural abundances // Contrib. Mineral. Petrol., v.136(3), p.313-324.

Cherny S.D., Fomin A.S., Yanygin Ju.T., Banzeruk V.I , Kornilova V.P. (1998) Geology and composition of the Nakyn field kimberlite pipes and diamond properties (Yakutia) // 7-th IKC. Kape Town. Exstented Abstracts. P. 9-10.

Coleman R.G., Lee, D.E., Beatty, L.B. and Brannock, W.W., (1965). Eclogites and eclogites: their differences and similarities. Bull. Geol. Soc. Amer. 76, 3, 483-508

Grutter H., Latti D., Menzies A. (2006) Cr-Saturation Arrays in Concentrate Garnet Compositions from Kimberlite and their Use in Mantle Barometry // Journal of Petrology, 1-20.

Mattey, D., Lowry, D., Macpherson, C., (1994). Oxygen isotope composition of mantle peridotite. Earth Planet. Sci. Lett. 128, 231-241

McDonough, W.F. and. Sun S. (1995) The composition of the Earth'. Chemical Geology 120. p.223-253.

Norman, M.D., Pearson, N.J., Sharma, A.,Griffin, W.L. (1996). Quantitative analysis of trace elements in geological materials by laser ablation ICPMS: instrumental operating conditions and calibration values of NIST glasses. Geostand. Newsl. 20, 247-261.

Ponomarenko, A.I., Leskova N.V. (1980). Peculiarities of chemical composition of minerals of alkremites from kimberlite pipe "Udachnaya". Dokl. Akad. Nauk SSSR 252(3), 707-711 (in Russian)

Ponomarenko, A.I. (1975). Alkremite - a new variety of aluminuous hyperbasite xenoliths from the kimberlites of Udachnaya pipe. Doklady Akad Nauk U.S.S.R., 225 (4), 928-931 (in Russian).

Sablukova L.I., Sablukov S.M., Stegnitsky Yu.B. and Banzeruk V.I. (2008) Mantle xenoliths of the Nyurbinskaya pipe (Yakutia): relicts of weakly metasomatized lithospheric mantle. 9-th IKC. Frankfurt. Exstented Abstracts. No. 9IKCA-00163.

Taylor L.A., Spetsius Z.V., Wiesli R., Anand M., Promprated P., and Valley J.W. (2003) The origin of mantle peridotites: crustal signatures from Yakutian kimberlites. $8^{\text {th }}$ IKC. Victoria. Exstented Abstracts. 